University of Nebraska - Lincoln

DigitalCommons@University of Nebraska - Lincoln

Space, Cyber, and Telecommunications Law

Program Faculty Publications

2018

Unmanned Aerial Vehicles: Their Use of Satellite Services and (Space) Law

Frans von der Dunk

Follow this and additional works at: https://digitalcommons.unl.edu/spacelaw

Part of the Air and Space Law Commons, Comparative and Foreign Law Commons, International Law Commons, Military, War, and Peace Commons, National Security Law Commons, and the Science and Technology Law Commons

This Article is brought to you for free and open access by the Law, College of at DigitalCommons@University of Nebraska - Lincoln. It has been accepted for inclusion in Space, Cyber, and Telecommunications Law Program Faculty Publications by an authorized administrator of DigitalCommons@University of Nebraska - Lincoln. 
Published as a chapter in Innovation in Outer Space: International and African Legal Perspectives, 5th and 6th Luxembourg Workshops on Space and Satellite Communication Law (M. Hofmann and P. J. Blount, editors), pages 155-170 (Baden-Baden, Germany: Nomos).

Copyright (C) 2018 Frans G. von der Dunk. Used by permission.

\title{
Unmanned Aerial Vehicles: Their Use of Satellite Services and (Space) Law
}

\author{
Frans von der Dunk
}

Harvey and Susan Perlman Alumni and Othmer Professor of Space Law, Nebraska College of Law, University of Nebraska-Lincoln, Lincoln, Nebraska, USA

\begin{abstract}
This chapter represents an effort to identify the components of international space law that apply to the use of unmanned aerial vehicles (UAVs). It argues that, while other national and international regimes of law apply to UAV activities, international space law is implicated only to the extent that UAV technology relies on satellite services for control and guidance purposes.
\end{abstract}

\section{Introduction: UAVs and space law?}

Drones, or, more officially, unmanned aerial vehicles (UAVs), ${ }^{1}$ are among the most important, challenging, but also controversial topics of today in international law. Machines defined or loosely labeled as UAVs are increasingly used for making fascinating but also intrusive pictures from above, which raises issues of privacy and trespassing, and other such machines are used for taking out terrorists or other military opponents - and sometimes killing innocent bystanders in the process.

For simplicity's sake we might picture these two generic uses to represent the two ends of a scale of a broad array of technologies used for a broad array of activities all qualifying as UAVs: on the one end of the scale, small, almost toylike instruments flying sometimes as low as only a handful of meters and used for, by and large, peaceful, sometimes even merely entertainment purposes, and on the other end small-helicopter-sized vehicles capable of operating at altitudes of tens of kilometers and launching missiles precisely to targets back on earth. 
One way or another, these new developments and the varying interests in monitoring and controlling, alternatively stimulating, and further extending them, time and again also gave rise to questions regarding what "space law" had to say about them. Were such activities forbidden, conditioned, controlled, or otherwise legally conditioned by space law?

This chapter represents an effort to try to answer that question, so far at a rather highly abstract level. It will largely focus on international space law, noting all the while that other regimes of law, national or to some extent even international, might or would also have regulated DAV-activities. This in turn means that this analysis is not complete by far, at least from the perspective of analyzing the legal aspects and parameters of UAV operations and activities.

In order to address the question regarding the extent to which UAVs are subject to space law and what boundaries space law would provide for their operations, it is first important to determine what "space law" is. "Space law" then, as for the international part thereof constituting a branch of general public international law,,$^{2}$ can be defined somewhat more precisely as "every legal or regulatory regime having a significant impact, even if implicitly or indirectly, on at least one type of space activity or major space application." ${ }^{3}$

Following a long-standing, largely theoretical debate on the respective spheres of application of space law and air law, as the other main body of (international but also national) law dealing with activities above the Earth's surface, two main doctrinal approaches have emerged which address in greater detail the scope of space law, actual as well as conceptual.

\section{Space law or air law-The "functionalist" approach}

Under the so-called "functionalist" approach, determining which of the two legal regimes applies to a certain activity, event, or situation above the earth's surface should follow a determination of the fundamental character of the activity, event, or situation at issue. Is it essentially a "space" activity, in terms of type of operations (such as launching a satellite or astronauts) and/or technology (such as rockets being launched vertically using rocket propulsion and satellites in orbit using radio frequencies)? Or is it essentially an "aviation" activity, again in terms of type of operations (such as flying humans or cargo from one place on earth to another) and/or technology (such as aircraft taking off and landing in almost horizontal modes using wings to benefit from the upward lift of the air)?

In other words: following this approach, if a UAV would be a "space object," it would be subject to space law ; if it would be an "aircraft," it would be subject to air law. ${ }^{5}$

"Aircraft" is defined quite precisely at the international level, as "any machine that can derive support in the atmosphere from the reactions of the air other than the reactions of the air against the earth's surface." 6 As a UAV is usually being defined as an "aircraft without a human pilot on board," it will be obvious that indeed they would seem to fall squarely within the definition of "aircraft" and hence to that extent be subject to air law. Any UAVs with wings or rotors as well as any balloons labeled UAVs would thus qualify as aircraft and be subject to those parts of air law of which application is triggered by a 
device involved being an aircraft. This does not however in itself negate the possible application of space law to operations with such UAVs, as in principle two (or even more) legal regimes could come to be applied to one and the same activity, event, or situation.

Additionally, another issue arises here. In reality, the legal regimes applicable to aircraft as developed over the last century or so were largely based on an (usually unspoken) assumption, namely that aircraft are flown by human pilots on board. These manned aspects of aviation operations are key to arrangements on safety such as crew certification, ${ }^{8}$ traffic management as it depends upon instant decision-making and maneuverability by (a) pilot(s) on board, ${ }^{9}$ and liability arrangements which prominently include issues of damage to passengers and cargo. ${ }^{10}$

UAVs, in contrast, are by definition unmanned, which is probably why the comparison with space objects - so far being overwhelmingly unmanned as well-is so often made. Because so much of space law addresses space objects as essentially remotely guided and unmanned objects just like UAVs, future legislators and regulators on UAVs may still occasionally look to existing space law for guidance in their development of such future legislation and regulation. This does not, of course, in and of itself mean that UAVs are, as such, potentially or likely qualifying as space objects, such as to trigger the applicability of space law in addition to air law.

A further problem here is that a space object as far as international treaty law is concerned is only partly "defined," as "includ[ing] component parts of a space object as well as its launch vehicle and parts thereof." ${ }^{11}$ However, doctrine has meanwhile been able to come up with a slightly more comprehensive and helpful definition, which could be summarized as "any man-made object which is at least attempted to be physically brought into outer space."12

The definition of a space object thus finally raises another issue at this point relative to UAVs. If a space object indeed is defined with reference to the aim to bring it into "outer space," this begs the question as to what "outer space" refers to-which in tum brings analysis to the other approach to applying air law respectively space law. This still is not likely to include UAVs, as most or indeed all of them will constitute neither an object intended for outer space itself, nor a launch vehicle or a component part of something else to be brought into outer space, but ultimately that of course depends on where outer space is supposed to begin.

\section{Space law or air law-The "spatialist" approach}

Under the so-called "spatialist" approach then, determining which of the two legal regimes applies to a certain activity, event, or situation above the earth's surface should follow a determination of where such activity, event, or situation takes place: in airspace or in outer space. Following this approach, for the current discussion that means that if (respective to the extent that) a DAV-operation takes place in outer space it would be subject to space law ${ }^{13}$; whereas if (respective to the extent that) it takes place in airspace, it would be subject to air law. ${ }^{14}$

This approach is corroborated by the very fundamental legal difference between the two realms. While outer space is not subject to appropriation by any state and hence is best 
qualified as an "international realm" or a "global commons"15; airspace is subject to the full sovereignty of the underlying state, ${ }^{16}$ which only leaves the airspaces above the high seas to be qualified as an "international realm." 17

That obviously then raises the issue of definition of "airspace" respective to "outer space." In this respect, however, neither the Chicago Convention nor the Outer Space Treaty provide any clear-cut definitions. As for the Chicago Convention, that made sense historically speaking, since at the time no one-except for a few theoretical treatises-legally addressed any higher realm which might possibly not be considered airspace. As for the aviation operations it addressed, regardless of what exact altitude they might have reached, these were never contested as to their taking place in airspace and hence if above some state's territory or territorial waters, plainly considered to fall within such a state's territorial sovereignty.

That obviously changed with Sputnik in 1957-yet in spite of the many discussions ever since addressing the issue, no consensus so far has arisen as to the altitude at which airspace exactly was supposed to give way to outer space. ${ }^{18}$ Some states, including most notably the United States, even refused to agree on the need to establish a boundary, for reasons harking back - as far as the legal ones were concerned - to the "functionalist" approach and the absence of a need to provide for such a boundary. Even among the states and experts agreeing in principle on the need for a boundary, a number of theories (such as that of lowest perigee or highest aerodynamic lift) were applied to arrive at - certainly early onwildly differing numbers.

The most that can be said as of today is that, with the caveats made above, a gradual convergence could be seen on an altitude of $100 \mathrm{~km}$ above sea level as the (at least politically speaking) most reasonable lower boundary of outer space. As of now, this precise number has been referenced in this precise context in the national space legislation of four countries: Australia, ${ }^{19}$ Kazakhstan, ${ }^{20}$ Denmark, ${ }^{21}$ and Nigeria. ${ }^{22}$ In addition, more indirect references can been found in other state-originating documents as well as some non-state documents. ${ }^{23}$

Such a boundary-line from a practical perspective does seem to be a workable provisional solution. So far, only a few very special satellites or other space objects are known to have been able to complete an orbit around the earth at altitudes below a $100 \mathrm{~km}$, whereas no vehicle making use of the upward lift of the air has been able to fly close to such altitudes (unless using non-aircraft technologies).

As it turns out also such a spatialist approach would rule out the applicability of space law to UAVs as such. The record altitudes so far registered for UAVs refer to $12.5 \mathrm{~km}$ for devices with rotors, $29.5 \mathrm{~km}$ for devices with wings, and $53 \mathrm{~km}$ for balloons ${ }^{24}$-all clearly far below any altitude that could sensibly be argued to constitute "outer space." Consequently, also under a spatialist approach UAV operations are essentially subject to air law, as premised on the sovereignty of the underlying state over its airspace-as well as any other national law and regulation that such underlying state may wish to extend to its airspace, such as criminal law. ${ }^{25}$

Following this, for instance the entry into a state's airspace without that state's consent is illegal, unless justified as an exception under international law in terms of either distress or (particularly relevant in the case of drones used for antiterrorist actions in other countries) self-defense or other legitimate uses of force in the international arena. Likewise- 
particularly relevant for the other end of the scale, the small UAVs used for civil, commercial, or hobby purposes - national laws on privacy, trespassing, and interference with property rights, liability for damage, and intellectual property rights apply in the respective airspaces of the countries where such UAVs operate. Also issues of air navigation and traffic management, in order to make sure DAV-operations would never endanger commercial or civil aviation, are subject to national legal regimes (and some international harmonization or coordination as per the Chicago Convention ${ }^{26}$ ).

Freedom of flight, from such a perspective, may exist only over the high seas, although on the one hand relevant internationally agreed rules of the law of the sea might limit such freedoms, and on the other hand the requirement for states to register such vehicles and thereby exercise jurisdiction over them, may still "import" national legal limitations on such operations over the high seas.

\section{Space law and UAVs-The involvement of satellites}

Following the extensive analysis just given, the only area where space law will be fundamentally engaged in regulating the activities of UAVs as of now is where they are controlled and guided by satellites - which in turn undoubtedly are space objects falling within the scope of space law under the functionalist approach and do by and large operate in outer space, thus also falling within the scope of space law under the spatialist approach.

On the one hand, this means that such satellite control and guidance has to take place within the general parameters of international space law, such as most notably of the Outer Space Treaty, the Liability Convention, and the Registration Convention. It should, for example, constitute a "use of outer space ... for the benefit and in the interests of all countries," ${ }^{27}$ which of course severely limits the legitimate possibilities of using satellites for the guidance of armed drones. It should not-at least, not without further consultation with states potentially affected-interfere in a harmful manner with other legitimate activities in outer space and, by proxy, by and large on Earth or in airspace as well. ${ }^{28}$ Private operators providing such satellite control and guidance services should be appropriately authorized and continuously supervised by the relevant national authorities. ${ }^{29}$ The satellites involved should also be appropriately registered both nationally and internationally. ${ }^{30}$

Also, any such satellite causing damage could be subject to the provisions of Article VII of the Outer Space Treaty and the Liability Convention. It should be noted here, however, that the definition of damage under the latter, as "loss of life, personal injury or other impairment of health; or loss of or damage to property of States or of persons, natural or juridical or property of international intergovernmental organizations" "caused by [a] space object," 31 is generally understood to refer to direct damage caused by kinetic impact, so as to rule out any indirect damage caused by a UAV controlled and/or guided by such a satellite..$^{32}$ That is to say that, at least, the Liability Convention could not serve as a legal basis for claims regarding such damage.

Beyond those fairly general parameters, the Outer Space Treaty provides for the freedom of activities in outer space as a baseline, ${ }^{33}$ where further limits are only imposed by general international law, in this case notably as per the UN Charter. ${ }^{34}$ Thus, the use of 
such satellites should comply with the requirements of maintenance of international peace and security, and the promotion of international cooperation and understanding. ${ }^{35}$

Furthermore, UAVs in military service also if controlled and guided by satellites should comply with the legal limits to the threat or use of force, which under general international law is in principle prohibited against other states ${ }^{36}$ with, arguably, four main exceptions. First, the UN Charter recognizes the right of self-defense against an armed attack, as long as the UN Security Council has not taken appropriate action. ${ }^{37}$ Second, the UN Charter under circumstances actually calls upon its member states to use force, within a specific UN mandate, against states or other actors violating the international legal order at a very high level of severity. ${ }^{38}$ Third, outside of the UN Charter often a(n older and broader) customary right of self-defense has been recognized, although subject to considerable debate in view of the potential abuse of such a right. ${ }^{39}$ Four, there might be forms of use of force not meeting the threshold contemplated by the prohibition on the use or threat of force contemplated by Article 2(4) of the UN Charter, for instance as directed against nonstate actors. ${ }^{40}$

On the other hand, the specific use of satellite orbits/orbital slots and satellite frequencies also for control and guidance of UAVs has to fall within the parameters of international satellite communication law as principally framed by the ITU Constitution, ${ }^{41}$ ITU Convention, ${ }^{42}$ and Radio Regulations. ${ }^{43}$

The first point of note here, in particular as for drones used for military operations, concerns the fact that military satellites are, as such, excluded from the scope of the regime developed under the auspices of the International Telecommunication Union (ITU) pursuant to the ITU Constitution, the ITU Convention, and the Radio Regulations. ${ }^{44}$ Obviously, however, the laws of physics will and actually do cause military satellite operators to take civil satellite usage per the ITU-regime into consideration, as any frequency used by two operators at the same time and place in principle results in white noise for both.

Furthermore, the ITU regime applies only to frequency usage with international ramifications, which includes satellites and orbit(al slot)s, but all other aspects of satellite operations-including for instance licensing - are a matter of national law. Thus, the use of a satellite for UAV control and guidance exclusively within national airspace and without the potential of interference with international frequencies would again be subject to the relevant state's domestic sovereignty. With those caveats, the frequencies and the attendant orbital slots or orbits to be used by satellites for controlling and guidance of UAVs have to fit within the extended process of allocation of frequency-bands to types of services, allotments of frequencies to certain services, and assignment to the relevant operators thereof. ${ }^{45}$

In view of the relative novelty of UAVs and their operations, until recently no specific frequency-bands were allocated to this kind of service, which left it unclear whether specific services and their operators could be allotted/assigned frequencies under different headings within Article 1 of the Radio Regulations. One could have considered UAV control and guidance, for example, to be comprised within the "mobile-satellite service," 46 the "aeronautical mobile-satellite service," ${ }^{77}$ the "aeronautical mobile-satellite $(\mathrm{OR})^{* *}$ service," 48 the "radiodetermination-satellite service," 49 the "radionavigation-satellite service," 50 the "safety service," 51 and/or the "special service." 52 
Then, however, at the 2015 World Radio Conference (WRC), the ITU conference held usually every three or four years to revise as necessary the Radio Regulations, ${ }^{53}$ ITU-R Resolution 155 was adopted. ${ }^{54}$ This Resolution allows for assignments of frequencies within a set of frequency bands to be granted to UAV operators using Fixed Satellite Service (FSS) networks under certain conditions, which include development by ICAO of appropriate standards and recommended practices for safe operations. ${ }^{55}$ In other words, ITU has now provided a first level of clarity and clearance regarding the inclusion of satellite controlled and guided UAV operations in the regime of legitimate use of space frequencies, but many details still need to be sorted out and negotiated in this respect.

\section{Space law as a model for UAV legislation and regulation}

The other potential area of DAV-operations where space law might be or become relevant, as mentioned before, concerns the use of the latter as a model for legislation and regulation of the former.

Here, it first has to be noted that, though they are indeed without pilots on board, UAVs are still very much maneuverable and hence could better be equated from that perspective with manned spacecraft. In other words, UAV operations-military ones left aside, as they assume lack of consent by the state concerned in the first place and hence would be subject to international law on the use of force-need (to be part of) a traffic management system providing for optimum integration of any vehicles in the same physical space, whether UAVs, other aircraft, or spacecraft.

As of yet, however, there is no traffic management system for manned spacecraft, certainly not at the international level, ${ }^{56}$ or, for that matter, for space objects as such beyond the rudimentary ITU-regime for relatively difficult-to-maneuver satellites and the even more rudimentary registration as per the Registration Convention. This means effectively that even in international airspaces, UAVs would much more sensibly be subjected to air traffic management-not only are UAVs aircraft but air traffic management both nationally and internationally is a well-weathered and legally framed environment, which so far even has been able to take care of the occasional launches of space objects inevitably passing through certain portions of airspace.

To the extent there is, as yet, one national legal regime providing for some sort of traffic management of manned space objects, it concerns the US Commercial Space Launch Act ${ }^{57}$ - which however does not use the term "space object," instead opting for "launch vehicle," which is defined as "(A) a vehicle built to operate in, or place a payload or human beings in, outer space; and (B) a suborbital rocket." 58 The Act provides for the authority of the US Federal Aviation Administration's Office for Commercial Space Transportation to license all activities of those vehicles, also if manned. ${ }^{59}$ This authority includes the possibility to grant "experimental permits" for activities not even necessarily themselves aiming for outer space-as long as, however, the ultimate goal is still to test technologies to be used in outer space. ${ }^{60}$ Thus, it would indeed be questionable whether such an approach would ever be applied to UAVs even in the domestic US context without further ado. 


\section{Conclusion}

Most importantly, the above analysis basically debunks the often-held understanding that space law would be a major factor in determining, either as of now or in the future, the legal ramifications of and parameters for the use of UAVs. Only to the extent that satellites provide control and guidance of UAVs would current space law become involved, which as far as military and antiterrorist DAV-operations are concerned would notably include general public international law in the area of the use of force. And only to the extent of the need to develop a proper traffic management system integrating the operations of UAVs, other aircraft and spacecraft alike, certainly as long as operating in the more trafficdense areas around the globe (read major parts of the airspaces around the world) could space law in theory be of interest-but in practice, thus far, is of little help in the absence of anything coming close to a space traffic management system in the first place, with the possible exception of the United States.

\section{Notes}

1. See, e.g., https://en.wikipedia.org/wiki/Unmanned_aerial_vehicle (last visited 5 September 2016).

2. See F. G. von der Dunk, International space law, in Handbook of Space Law (Eds. F. G. von der Dunk \& F. Tronchetti) (2015), 29ff., including doctrine referenced in fn. 1.

3. F. G. von der Dunk, Preface, in Handbook of Space Law (Eds. F. G. von der Dunk \& F. Tronchetti) (2015), xxvi.

4. Cf., e.g., the Convention on International Liability for Damage Caused by Space Objects (hereafter Liability Convention), London/Moscow/Washington, done 29 March 1972, entered into force 1 September 1972; 961 UNTS 187; TIAS 7762; 24 UST 2389; UKTS 1974 No. 16; Cmnd. 5068; ATS 1975 No. 5; 10 ILM 965 (1971) and the Convention on Registration of Objects Launched into Outer Space (hereafter Registration Convention), New York, done 14 January 1975, entered into force 15 September 1976; 1023 UNTS 15; TIAS 8480; 28 UST 695; UKTS 1978 No. 70; Cmnd. 6256; ATS 1986 No. 5; 14 ILM 43 (1975); the application of both of which as the titles already indicate fundamentally hinges on the involvement of a space object. See further, e.g., V. Kopal, The Question of Defining Outer Space, 8 Journal of Space Law (1980), 154ff.; T. Neger \& E. Walter, Space Law-An Independent Branch of the Legal System, in Outer Space in Society, Politics, and Law (Eds. C. Brünner \& A. Soucek) (2011), 237-41; B. Cheng, The Legal Regime of Airspace and Outer Space; The Boundary Problem, Functionalism versus Spatialism: The Major Premises, 5 Annals of Air and Space Law (1980), 323-61.

5. Cf., e.g., the Convention on International Civil Aviation (hereafter Chicago Convention), Chicago, done 7 December 1944, entered into force 4 April 1947; 15 UNTS 295; TIAS 1591; 61 Stat. 1180; Cmd. 6614; UKTS 1953 No. 8; ATS 1957 No. 5; ICAO Doc. 7300; the application of which for many of its clauses (see, e.g., Arts. 5-21) fundamentally hinges on the involvement of an aircraft. See further, e.g., M. Chatzipanagiotis, The Legal Status of Space Tourists in the Framework of Commercial Suborbital Flights (2011), 19-20, 43-44; M. Gerhard, Space Tourism - The Authorisation of Suborbital Space Transportation, in National Space Legislation in Europe (Ed. F. G. von der Dunk) (2011), 264-65, 268-69; R. Abeyratne, Space Tourism-Parallel Synergies between Air and Space Law?, 53 Zeitschrift für Luft- und Weltraumrecht (2004), 190-93. 
6. E.g., Annex 7 to the Chicago Convention (supra n. 5), Aircraft nationality and registration marks, 5th ed., July 2003, Definitions; Annex 8, Airworthiness of aircraft, 10th ed., April 2005, Definitions.

7. Cf. also Art. 8, Chicago Convention (supra n. 5), addressing "Pilotless aircraft."

8. Cf. Art. 32, Chicago Convention (supra n. 5).

9. Cf. Art. 28, Chicago Convention (supra n. 5).

10. Cf. a range of treaties on contractual liability, from the Convention for the Unification of Certain Rules Relating to International Transportation by Air, Warsaw, done 12 October 1929, entered into force 13 February 1933; 137 LNTS 11; USTS 876; UKTS 1933 No. 11; ATS 1963 No. 18, to the Convention for the Unification of Certain Rules for International Carriage by Air, Montreal, done 28 May 1999, entered into force 4 November 2003; 2242 UNTS 350; ICAO Doc. 9740; S. Treaty Doc. No. 106-45; 48 Zeitschrift für Luft- und Weltraumrecht 326 (1999).

11. Art. I(d), Liability Convention (supra n. 4); Art. I(b), Registration Convention (supra n. 4). See further, e.g., L. J. Smith \& A. Kerrest de Rozavel, The 1972 Convention on International Liability for Damage Caused by Space Objects, in Cologne Commentary on Space Law (Eds. S. Hobe, B. Schmidt-Tedd \& K. U. Schrogl) Vol. II (2013), 113-14; B. A. Hurwitz, State Liability for Outer Space Activities in Accordance with the 1972 Convention on International Liability for Damage Caused by Space Objects (1992), 20-21.

12. Von der Dunk, supra n. 2, 87.

13. Cf., e.g., Arts. I-IV, VI, Treaty on Principles Governing the Activities of States in the Exploration and Use of Outer Space, including the Moon and Other Celestial Bodies (hereafter Outer Space Treaty), London/Moscow/Washington, done 27 January 1967, entered into force 10 October 1967; 610 UNTS 205; TIAS 6347; 18 UST 2410; UKTS 1968 No. 10; Cmnd. 3198; ATS 1967 No. 24; 6 ILM 386 (1967); the application of which fundamentally hinges on the occurrence of an activity, event, or situation in outer space. See further, e.g., Kopal (supra n. 4), 154ff.; Neger \& Walter (supra n. 4), 237-41; Cheng (supra n. 4), 323-61.

14. Cf., e.g., Art. 1, Chicago Convention (supra n. 5); which posits a state's sovereignty over its airspace as the most fundamental premise of air law, triggering the application of all national law premised on national territorial sovereignty. See further, e.g., M. Milde, International Air Law and ICAO (2nd ed.) (2012), 33ff.; S. Kaul, Chicago Convention Revisited: Review of Chicago Convention and Bilateralism, in Current Developments in Air and Space Law (Eds. R. Singh, S. D. Rao \& S. Kaul) (2012), 1-3.

15. See esp. Art. II, Outer Space Treaty (supra n. 13). Further, e.g., S. R. Freeland \& R. Jakhu, Article II, in Cologne Commentary on Space Law (Eds. S. Robe, B. Schmidt-Tedd \& K. U. Schrogl) Vol. I (2009), 48-55; L. Viikari, From Manganese Nodules to Lunar Regolith (2002), 17-21.

16. See esp. again Art. 1, Chicago Convention (supra n. 5).

17. Cf. Art. 87(1)(b), United Nations Convention on the Law of the Sea, Montego Bay, done 10 December 1982, entered into force 16 November 1994; 1833 UNTS 3 \& 1835 UNTS 261; UKTS 1999 No. 81; Cmnd. 8941; ATS 1994 No. 31; 21 ILM 1261 (1982); S. Treaty Doc. No. 103-39; also Milde, supra, n. 14, 37-41.

18. For a detailed discussion of this see, e.g., Von der Dunk, supra n. 2, 60-72.

19. Cf. Sec. 8, sub 16th, 21st, 33rd, \& 35th bullet, An act about space activities, and for related purposes, No. 123 of 1998, assented to 21 December 1998; National Space Legislation of the World, Vol. I (2001), at 197; as amended by Space Activities Amendment Act, An Act to Amend the Space Activities Act 1998, No. 100 of 2002, assented to 10 November 2002; http://www.austlii.edu.au/ au/legis/cth/num_act/saaa2002247/. 
20. Cf. Art. 1(6), Law of the Republic of Kazakhstan on Space Activities, of 6 January 2012, 2012 No. 528-IV; http://www.unoosa.org/pdf/spacelaw/national/kazakhstan/528-IV_2012-01-06E.pdf.

21. Cf. Sec. 4(4), Law on activities in outer space (Lov om aktiviteter i det ydre rum), Passed by Parliament with the third treatment, 3 May 2016; Parliament Gazette, 2015-17, No. L 128.

22. Cf. Sec. 43 , 1st \& 6th paras., Regulations on the Licensing and Supervision of Space Activities, $2015 \mathrm{draft}$, provided courtesy of NASRDA; copy in possession of the author.

23. Interestingly, even in the United States the Federal Regulations at some point refer to this altitude: see § 772.1, "Definitions of terms as used in the Export Administration Regulations (EAR)," defines "[s]pace-qualified" as "[d]esigned, manufactured, or qualified through successful testing, for operation at altitudes greater than $100 \mathrm{~km}$ above the surface of the Earth," $78 \mathrm{Fed}$. Reg. 31,440 (2013). For a further list of examples see, e.g., Von der Dunk, supra n. 2, 69-71.

24. See https://en.wikipedia.org/wiki/Flight_altitude_record (last visited 9 September 2016).

25. Cf., e.g., Arts. 3, 4, Convention on Offences and Certain Other Acts Committed on Board Aircraft, Tokyo, done 14 September 1963, entered into force 4 December 1969; 704 UNTS 219; TIAS 6768; UKTS 1969 No. 126; Cmnd. 2261; ATS 1970 No. 14; 2 ILM 1042 (1963); ICAO Doc. 8364.

26. Further esp. to Arts. 37, 38, Chicago Convention (supra n. 5); Annex 2, Rules of the air; and Annex 11, Air Traffic Services.

27. Art. I, Outer Space Treaty (supra n. 13).

28. Cf. Art. IX, Outer Space Treaty (supra n. 13).

29. Cf. Art. VI, Outer Space Treaty (supra n. 13).

30. See Art. VIII, Outer Space Treaty (supra n. 13); Arts. II-IV, Registration Convention (supra n. 4).

31. Art. I (a) resp. Arts. II, III, Liability Convention (supra n. 4).

32. The closest analogies discussed so far would concern (1) the damage caused by, e.g., aircraft as a consequence of navigation satellites providing them with erroneous signals; so far only one author has made the case for inclusion of this damage in the scope of the Liability Convention; see B. D. K. Henaku, The Law on Global Air Navigation by Satellite: An Analysis of Legal Aspects of the ICAO CNS/ATM System (1998), 221; and (2) the damage caused by a remote sensing satellite operator not forwarding information which might have helped to mitigate the (consequences of the) 2004 Indian Ocean tsunami; see A. Ito, Legal Aspects of Satellite Remote Sensing (2011), 19194, discussing several claims brought against NOAA in this context.

33. See Arts. I, II, Outer Space Treaty (supra n. 13).

34. See Art. III, Outer Space Treaty (supra n. 13); explicitly referring to the Charter of the United Nations (hereafter UN Charter), San Francisco, done 26 June 1945, entered into force 24 October 1945; USTS 993; 24 UST 2225; 59 Stat. 1031; 145 UKTS 805; UKTS 1946 No. 67; Cmd. 6666 \& 6711; CTS 1945 No. 7; ATS 1945 No. 1.

35. See, e.g., Art. 1, UN Charter (supra n. 34).

36. See Art. 2(4), UN Charter (supra n. 34).

37. See Art. 51, UN Charter (supra n. 34).

38. Cf. Arts. 42ff., UN Charter (supra n. 34).

39. Cf., e.g., O. Dörr, Use of Force, Prohibition of, in The Max Planck Encyclopedia of Public International Law (Ed. R. Wolfrum), Vol. X (2012), 615-16.

40. Cf., e.g., Dörr, supra n. 39, 616-18.

41. Constitution of the International Telecommunication Union (hereafter ITU Constitution), Geneva, done 22 December 1992, entered into force 1 July 1994; 1825 UNTS 1; UKTS 1996 No. 24; 
Cm. 2539; ATS 1994 No. 28; Final Acts of the Additional Plenipotentiary Conference, Geneva, 1992 (1993), at 1; as amended a few times thereafter.

42. Convention of the International Telecommunication Union (hereafter ITU Convention), Geneva, done 22 December 1992, entered into force 1 July 1994; 1825 UNTS 1; UKTS 1996 No. 24; Cm. 2539; ATS 1994 No. 28; Final Acts of the Additional Plenipotentiary Conference, Geneva, 1992 (1993), at 71; as amended a few times thereafter.

43. Radio Regulations Articles, Edition of 2012 (hereafter Radio Regulations), www.itu.int/pub/RREG-RR-2012 (last visited 9 September 2016).

44. See Art. 48, ITU Constitution (supra n. 41).

45. See further in detail, e.g., F. G. von der Dunk, Legal aspects of satellite communications, in Handbook of Space Law (Eds. F. G. von der Dunk \& F. Tronchetti) (2015), 464-84.

46. Defined by Art. 1.25, Radio Regulations (supra n. 43), as "A radiocommunication service: between mobile earth stations and one or more space stations, or between space stations used by this service (...). This service may also include feeder links necessary for its operation."

47. Defined by Art. 1.35, Radio Regulations (supra n. 43), as "A mobile-satellite service in which mobile earth stations are located on board aircraft."

48. Defined by Art. 1.37, Radio Regulations (supra n. 43), as "An aeronautical mobile-satellite service intended for communications, including those relating to flight coordination, primarily outside national and international civil air routes."

49. Defined by Art. 1.41, Radio Regulations (supra n. 43), as "A radiocommunication service for the purpose of radiodetermination involving the use of one or more space stations"; where Art. 1.9 defines "radiodetermination" as "The determination of the position, velocity and/or other characteristics of an object, or the obtaining of information relating to these parameters, by means of the propagation properties of radio waves."

50. Defined by Art. 1.43, Radio Regulations (supra n. 43), as "A radiodetermination-satellite service used for the purpose of radionavigation"; while Art. 1.46 defines an "aeronautical radionavigation service" as "A radionavigation service intended for the benefit and for the safe operation of aircraft," and Art. 1.47 defines an "aeronautical radionavigation-satellite service" as "A radionavigation-satellite service in which earth stations are located on board aircraft."

51. Defined by Art. 1.59, Radio Regulations (supra n. 43), as "Any radiocommunication service used permanently or temporarily for the safeguarding of human life and property."

52. Defined by Art. 1.60, Radio Regulations (supra n. 43), as "A radiocommunication service, not otherwise defined in this Section, carried on exclusively for specific needs of general utility, and not open to public correspondence."

53. Cf. Arts 3, 7, ITU Convention (supra n. 42).

54. Resolution 155 (WRC-15), Regulatory provisions related to earth stations on board unmanned aircraft which operate with geostationary-satellite networks in the fixed-satellite service in certain frequency bands not subject to a Plan of Appendices 30, 30A, and 30B for the control and nonpayload communications of unmanned aircraft systems in nonsegregated airspaces; Final Acts WRC-15, World Radiocommunication Conference, Geneva, 2015; 238.

55. See Resolution 155 (supra n. 54), "recognizing" sub b), "resolves" sub 1-19.

56. Cf. the IAA Cosmic Study on Space Traffic Management, International Academy of Astronautics (2006); also H. P. van Fenema, Legal aspects of launch services and space transportation, in Handbook of Space Law (Eds. F. G. von der Dunk \& F. Tronchetti) (2015), 405-17. 
57. Commercial Space Launch Act, 30 October 1984, Public Law 98-575, 98th Congress, H.R. 3942; 98 Stat. 3055; Space Law-Basic Legal Documents, E.111.3; as amended a few times thereafter and meanwhile codified as 51 U.S.C. 509.

58. Sec. 50902(8), 51 U.S.C. 509.

59. As per the 2004 amendments to the Commercial Space Launch Act (supra n. 57) pursuant to the Commercial Space Launch Amendments Act, 23 December 2004, Public Law 108-492, 108th Congress, H.R. 3752, 49 U.S.C.; 118 Stat. 3974.

60. The FAA did once, in 2013, license high-altitude balloon flights by Paragon aiming at an altitude of "only" $30 \mathrm{~km}$ under the Commercial Space Launch Act (supra n. 57), see letter FAA to P. L. Meredith, 26 September 2013, at www.faa.gov/about/office_org/headquarters_offices/agc/pol_ adjudication/agc200/interpretations/data/interps/2013/meredith-zuckertscoutt\&rasenberger\%20$\% 20(2013) \% 20$ legal\%20 interpretation.pdf (last accessed 10 September 2016); but this would not seem to be a viable legal precedent for UAVs.

\section{Bibliography}

1. B. Cheng, The Legal Regime of Airspace and Outer Space; The Boundary Problem Functionalism versus Spatialism: The Major Premises, 5 Annals of Air and Space Law (1980), 323-61.

2. F. G. von der Dunk, International space law, in Handbook of Space Law (Eds. F. G. von der Dunk \& F. Tronchetti) (2015), 29-126.

3. M. Milde, International air law and ICAO (3rd ed.) (2016).

4. L. J. Smith \& A. Kerrest de Rozavel, The 1972 Convention on International Liability for Damage Caused by Space Objects, in Cologne Commentary on Space Law (Eds. S. Hobe, B. Schmidt-Tedd \& K. U. Schrogl) Vol. II (2013), 92-226. 